\title{
THE ROLE OF THE GRANULOCYTE AS A SOURCE OF LYSOZYME IN ULCERATIVE COLITIS ${ }^{1}$
}

\author{
BY R. B. HIATT, C. ENGLE, C. FLOOD, AND A. KARUSH \\ (From the Departments of Surgery, Medicine, and Psychiatry, Columbia University College \\ of Physicians and Surgeons, and the Presbyterian Hospital, New York, N. Y.)
}

(Submitted for publication February 9, 1952; accepted May 12, 1952)

The presence of high concentrations of lysozyme in the stools of patients with ulcerative colitis has been demonstrated by a number of observers. It has been suggested that this enzyme may play a fundamental role in causing destruction of the colonic mucosa. Recent observations, showing that a high concentration of lysozyme is present also in granulation tissue and in leukocytes, have cast doubt on this hypothesis and suggest that the large amount of the enzyme in the feces of patients with ulcerative colitis is a result rather than a cause of the inflammatory process.

The present report summarizes a series of studies designed to elucidate the source of lysozyme in the stools in ulcerative colitis. Our observations lead us to believe that the enzyme content of the feces is derived predominantly from the white blood cells present in the intestinal wall and stools in this disease.

\section{REVIEW OF LITERATURE}

In 1922 Fleming (1) drew attention to a powerful bacteriolytic agent, which he named "Lysozyme," present in many body tissues and secretions of man and animals. He noted the high levels of this enzyme in tears, nasal secretion, egg white and leukocytes. Since then, many investigators have helped to clarify the nature of this enzyme, and it is now known to be a protein of low molecular weight capable of depolymerizing certain muco-polysaccharides. Meyer and Hahnel (2) contributed much toward the fundamental knowledge of this enzyme and devised an excellent viscosimetric technique for its quantitation in tissues and secretions, using as a substrate a mucopolysaccharide obtained from the micrococcus lysodeikticus.

1 Supported by a research grant from the National Institute of Mental Health, U. S. Public Health Service, Bethesda, Md., and the Latin American Fund for the Study of Gastro-Intestinal Diseases.
The original hope of the early investigators that lysozyme might be used as a therapeutic agent was dispelled by the finding that lysozyme had very little lytic action against pathogens (3). In 1948, Meyer and his associates (4) noted an increased amount of lysozyme in the stools of patients with intestinal ulcerative disease, i.e., regional ileitis and ulcerative colitis. They suspected that lysozyme played a primary role in the etiology of these diseases by removing the protective mucous lining of the gut, thus subjecting the mucous membrane to bacterial and/or enzymatic damage. Initial studies of instilling lysozyme into the intact or isolated portions of the gut of a dog, resulting in superficial ulcerations, seemed to confirm this point of view. However, the amount of lysozyme used was very large, and subsequent investigators, although confirming these observations, disagreed with the interpretation and extent of pathology (5). Also, it appeared unlikely that lysozyme had any effect on the mucus in the gut since the mucus could not be depolymerized in vitro (6).

It has been demonstrated conclusively by recent investigations that the titre of fecal lysozyme in patients with ulcerative colitis closely parallels the clinical course, in that the lysozyme titre rises with exacerbations and falls with remissions. Gray, Reifenstein, Benson, and Young (7) carefully recorded the fecal lysozyme titres of patients with ulcerative colitis in whom remissions were precipitated by ACTH, and clearly demonstrated the parallelism between the lysozyme titres and the clinical status of the patient. This relationship was found to be true of patients undergoing spontaneous remissions, as observed during the past three years in the Combined Ulcerative Colitis Clinic of the Columbia-Presbyterian Medical Center. When lysozyme inhibitors were given by mouth to patients with ulcerative colitis, as was done by Gray and associates, who used Aerosol (di-octyl sodium sulfo succinate) $(8)$, the fe- 
cal lysozyme titre fell to low levels without appreciably altering the course of the disease. These observations, plus the fact that lysozyme is found in high quantities in all granulation tissue (9), have led to the belief that lysozyme has no primary role in the etiology of ulcerative colitis, but that it is an accurate index of the degree of inflammatory involvement of the colon.

The fact that lysozyme is present in exudate and granulation tissue was known by most investigators of lysozyme $(9,10)$; however, the importance of this in ulcerative colitis was largely overlooked. In 1950, Sammons (10) suggested that "pus cells" were responsible for some of the lysozyme content of the stools of patients with ulcerative colitis, but he offered no clear-cut proof. Also in 1950 Gottschall, Pickering and Tabachnik (11), working in this laboratory, demonstrated clearly that lysozyme was to be found only in the granulocyte series (polymorphonuclear leukocytes, eosinophils in circulating blood and exudate) and again drew attention to the large numbers of granulocytes found in the stools of ulcerative colitis patients.

\section{PRESENT STUDIES}

We have attempted to correlate the number of granulocytes seen in microscopic examination of the stools in ulcerative colitis with the lysozyme titres, but no accurate correlation was possible because of cellular breakdown, making cell types unrecognizable. Therefore, we resorted to obtaining the specimens from the wall of the rectum by scraping with a blunt scoop during proctoscopic examination. When this material is stained by Wright's method, the cells are more recognizable and a rough correlation can be made between the number of granulocytes and lysozyme titre.

An observation not heretofore recorded was the high lysozyme titre found in the lining mucus of patients in complete clinical remissions from ulcerative colitis. Seventeen such determinations in 17 patients ranged from 69 to 310 units per cubic milliliter, with an average of 150 . One patient in remission while still receiving cortisone had a lysozyme titre of 150 units per cubic milliliter. In another patient with a rectal polyp and a normal colon, no lysozyme was found in the mucus removed from the rectal wall and no granulocytes were seen on microscopic examination. Micro- scopic examination of all specimens removed from patients with ulcerative colitis in remission uniformly revealed vast numbers of granulocytes.

However, the correlation of granulocytes and lysozyme does not completely answer the fundamental question of lysozyme source, since it is theoretically possible that the mucous membrane of the colon secretes lysozyme as a result of the same underlying mechanism that elicits a leukocytic response. The correlation of granulocytes and lysozyme also has the objectionable feature of being subject to interpretive error.

A new method was adopted in an attempt to overcome these deficiencies. It had been observed microscopically that most of the white cells in the material obtained by scraping the rectal mucous membrane were imbedded in the mucus from which they could not be separated by physical means. Shaking this combination of mucus and exudate with saline, centrifuging and determining the lysozyme content of the supernatant fluid always yielded negative results, while the residue of mucus and cells was always quite high in lysozyme content. In order to determine the exact source of lysozyme, the mucus had to be separated from the cells, and to do this, a supply of mucinase which had been extracted from the $V$ ibrio cholera was used. When this was first added to a saline suspension of mucus and cells obtained from a patient with ulcerative colitis and then incubated, the mucus lost its physical property of tenacity and could no longer be identified grossly. After centrifuging this specimen, it was found that for the first time, lysozyme appeared in the supernatant fluid as well as in the cellular residue, sometimes in almost equal amounts. The lysozyme in the supernatant portion could be from only two possible sources, the mucus itself or lysozyme left in active form after dissolution of the white cells. The exact source of lysozyme was not determined until a patient with an isolated loop of large intestine, which was completely detached from the fecal stream but in which there was active ulcerative colitis, was studied. It was possible to instill fluid in the proximal end of this isolated loop and obtain it from the distal end.

Theoretically, if the total source of the lysozyme were the invading granulocyte which leaves lysozyme in active form after dissolution of the cell 
body, the first washing of the gut loop after a long period of rest should show a significant titre of free lysozyme, which would appear in the supernatant fluid after depolymerization of the mucus and centrifugation. With a short period of rest, the lysozyme should be found only with the intact granulocytes in the residue of the centrifuged and depolymerized specimen.

Confirmation of this theoretical possibility was determined as follows:

\section{Method}

The isolated loop of colon of the patient mentioned above, after a 24-hour period of rest, was irrigated with $40 \mathrm{ml}$. of normal saline (Table I, Specimen A). A second time, ten minutes later, the loop was again irrigated (Specimen B), and a third irrigation was done after another ten minutes (Specimen $\mathrm{C}$ ). Each specimen was mixed vigorously and a $6 \mathrm{ml}$. aliquot taken. Mucinase powder was added to each aliquot and incubated until the solution was homogeneous and no more mucus could be demonstrated on the stirring rod. Each specimen was centrifuged for five minutes at high speed and $1 \mathrm{ml}$. of supernatant fluid removed for microscopic study and lysozyme determination. A microscopic study and lysozyme titre was then done on the residue of each specimen after discarding the remaining supernatant fluid.

\section{Results}

Microscopically: No cells were present in supernatant fluid of Specimen A, B, or C. In the residues of each, there were many packed leukocytes, predominantly granulocytes. In Specimen A, many of these cells were in the process of dissolution. In the residues of Specimens $B$ and $C$, the cells were intact.

Lysozyme titre: In Specimen A, lysozyme was found in high titres in both the supernatant and cellular residue. In Specimens B and C, lysozyme was found in significant quantities only in the cellular residue. Repeating the experiment yielded essentially the same result.

Controls: Mucinase incubated with granulocytes had no appreciable effect. Mucinase did not depolymerize the substrate used in the lysozyme determination.

Thus to our satisfaction, the source of at least the major portion of the lysozyme found in the stools of one patient with ulcerative colitis was found to be the invading granulocyte which left lysozyme in active form after cellular breakdown.

We then turned our attention to the lysozyme
TABLE I

Lysozyme and leukocytic content of cellular residue and supernatant fluid from isolated colonic loop in ulcerative colitis

\begin{tabular}{|c|c|c|c|}
\hline & $\begin{array}{l}\text { Specimen A } \\
\text { (washings after } \\
24 \text { hours rest) }\end{array}$ & $\begin{array}{l}\text { Specimen B } \\
\text { (second washing } \\
10 \text { minutes after } \\
\text { first irrigation) }\end{array}$ & $\begin{array}{c}\text { Specimen C } \\
\text { (third washing } \\
10 \text { minutes after } \\
\text { second irrigation) }\end{array}$ \\
\hline Supernatant & $\begin{array}{l}\text { Micro: no cells } \\
\text { Lysozyme: } 16.9 \\
\text { units }\end{array}$ & $\begin{array}{l}\text { Micro: no cells } \\
\text { Lysozyme: } 0 \\
\text { units }\end{array}$ & $\begin{array}{l}\text { Micro: no cells } \\
\text { Lysozyme: } 0 \\
\text { units }\end{array}$ \\
\hline Residue & $\begin{array}{l}\text { Micro: many } \\
\text { granulocytes; } \\
\text { a large number } \\
\text { in process of } \\
\text { degeneration } \\
\text { Lysozyme: } 29.3 \\
\text { units }\end{array}$ & $\begin{array}{l}\text { Micro: many } \\
\text { granulocytes, } \\
\text { mostly intact } \\
\text { Lysozyme: } 29.3 \\
\text { units }\end{array}$ & $\begin{array}{l}\text { Micro: many } \\
\text { granulocytes, } \\
\text { all intact } \\
\text { Lysozyme: } 14.6 \\
\text { units }\end{array}$ \\
\hline
\end{tabular}

titre of viable granulocytes found in the circulating blood of healthy adults. The method used to quantitate this titre follows. As a unit of measure, we chose the number of units of lysozyme found in $10^{7}$ granulocytes.

\section{Method}

\section{A. Collection of blood}

1. Prepare dry $50 \mathrm{ml}$. tube (plastic or glass) with a $20 \mathrm{ml}$. mark.

2. Add $0.4 \mathrm{ml}$. of $10 \%$ potassium oxalate solution (or other anti-coagulant). ${ }^{2}$ Evaporate to dryness in $\mathbf{5 0}$ $\mathrm{ml}$. tube to avoid volume error.

3. Prepare fresh fibrinogen solution $(310 \mathrm{mg}$. fibrinogen in $10 \mathrm{ml}$. distilled $\mathrm{H}_{2} \mathrm{O}$ or equivalent) (12).

4. Collect $20 \mathrm{ml}$. blood (from dry syringe or from blood bank), invert tube carefully several times to mix with anti-coagulant.

\section{B. Separation of leukocytes}

1. Add immediately $21 / 2 \mathrm{ml}$. of the fibrinogen solution to $20 \mathrm{ml}$. of blood. Mix by inversion.

2. Allow to stand at a slight angle for about one hour or until the supernatant plasma is about half the total volume.

3. Carefully remove the supernatant plasma suspension with a capillary pipet and rubber bulb and transfer to a graduated centrifuge tube $(15 \mathrm{ml}$.) or hematocrit tube.

4. Remove small sample of suspension, after mixing well, for WBC counts and differentials.

5. Centrifuge for about five minutes at full speed.

6. Note total volume of plasma and packed cells.

7. Remove clear supernatant plasma to the $1 \mathrm{ml}$. mark, thus leaving the packed cells in $1 \mathrm{ml}$. volume of plasma.

2 Heparin has been shown to be a mild inhibitor of free lysozyme. However, it has little effect on lysozyme contained in granulocytes as determined by comparison with oxylated blood. 
TABLE II

\begin{tabular}{|c|c|c|c|c|c|c|c|}
\hline \multicolumn{8}{|c|}{ Lysozyme content of $10^{7}$ granulocytes in healthy adults } \\
\hline Patient & $\begin{array}{c}\text { WBC of } \\
\text { plasma } \\
\text { suspension }\end{array}$ & $\begin{array}{c}\% \text { of } \\
\text { granulo- } \\
\text { cytes }\end{array}$ & $\begin{array}{r}\text { Tota } \\
\text { lysozy } \\
(1 \mathrm{ml} . \\
\text { plasn } \\
\text { suspens }\end{array}$ & $\begin{array}{l}\text { al } \\
\text { ime } \\
\text { of } \\
\text { na } \\
\text { sion) }\end{array}$ & $\begin{array}{r}\text { Pla } \\
\text { 8uspe } \\
\text { (m }\end{array}$ & \begin{tabular}{l|} 
asma \\
ension \\
ml.)
\end{tabular} & $\begin{array}{c}\text { Lysozyme } \\
\text { per } 10^{7} \\
\text { granulo- } \\
\text { cytes }\end{array}$ \\
\hline $\begin{array}{l}\text { J. D. } \\
\text { B. } \mathbf{M} . \\
\text { ? } \\
\text { R. H. } \\
\text { R. H. } \\
\text { R. H. } \\
\text { Duplicate } \\
\text { J. F. } \\
\text { Duplicate } \\
\text { A. B. } \\
\text { Duplicate } \\
\text { H. D. } \\
\text { C. F. }\end{array}$ & $\begin{array}{r}9,000 \\
8,900 \\
9,800 \\
12,850 \\
6,520 \\
4,900 \\
8,100 \\
4,720 \\
11,520 \\
13,640 \\
14,040 \\
7,200 \\
7,500\end{array}$ & $\begin{array}{l}\mathbf{3 0} \\
\mathbf{5 3} \\
\mathbf{6 5} \\
\mathbf{5 9} \\
\mathbf{6 4} \\
\mathbf{7 3} \\
\mathbf{5 6} \\
\mathbf{3 8} \\
\mathbf{6 6} \\
\mathbf{7 1} \\
\mathbf{7 3} \\
\mathbf{1 1} \\
\mathbf{2 7}\end{array}$ & $\begin{array}{r}9.1 \\
13.3 \\
25.3 \\
18.9 \\
20.1 \\
6.3 \\
8.9 \\
9.9 \\
37.9 \\
44.9 \\
35.9 \\
4.6 \\
9.8\end{array}$ & & & $\begin{array}{l}3.2 \\
9.5 \\
4.2 \\
4.7 \\
6.0 \\
3.5 \\
4.2 \\
6.0 \\
6.0 \\
7.5 \\
7.0 \\
5.3 \\
6.0\end{array}$ & $\begin{array}{r}9.7 \\
11.9 \\
9.5 \\
5.4 \\
8.0 \\
5.3 \\
4.7 \\
9.2 \\
8.3 \\
6.2 \\
5.0 \\
11.5 \\
8.0\end{array}$ \\
\hline \multicolumn{7}{|l|}{ Average } & 8.0 \\
\hline \multicolumn{8}{|c|}{ Lysozyme content of $10^{7}$ granulocytes in diseased states } \\
\hline Patient & & $\begin{array}{c}\text { WBC of } \\
\text { plasma } \\
\text { suspen- } \\
\text { sion }\end{array}$ & $\begin{array}{l}\text { \% of } \\
\text { granu- } \\
\text { locytes }\end{array}$ & $\begin{array}{r}\text { To } \\
\text { lysoz } \\
0 \\
\text { plas }\end{array}$ & $\begin{array}{l}\text { otal } \\
\text { zyme } \\
\text { of } \\
\text { isma }\end{array}$ & $\begin{array}{c}\text { Plasma } \\
\text { suspen- } \\
\text { sion } \\
(m l .)\end{array}$ & $\mid \begin{array}{c}\text { Lyso- } \\
\text { zyme } \\
\text { per } 10^{7} \\
\text { granu- } \\
\text { locytes }\end{array}$ \\
\hline O. F. & Ulcerative & 7,000 & 52 & & 6.6 & 6.0 & 12.2 \\
\hline T. S. & Ulcerative & 4,206 & 31 & & 4.4 & 6.0 & 5.6 \\
\hline L. P. & Cirrhosis of & 9,500 & 61 & & 6.7 & 9.0 & 7.0 \\
\hline A. $\mathbf{M}$. & $\begin{array}{l}\text { Rheumatoid } \\
\text { arthritis }\end{array}$ & 8,580 & 62 & & 0.8 & 8.6 & 8.9 \\
\hline J. K. & $\begin{array}{l}\text { Regional } \\
\text { ileitis }\end{array}$ & 10,100 & 80 & & 3.4 & 8.4 & 3.5 \\
\hline J. K. & $\begin{array}{l}\text { Chronic } \\
\text { infection }\end{array}$ & 15,000 & 76 & & 7.6 & 9.4 & 7.3 \\
\hline J. M. & $\begin{array}{l}\text { Lung ab- } \\
\text { scess }\end{array}$ & 8,280 & 36 & & 2.2 & 9.7 & 7.7 \\
\hline W. W. & $\begin{array}{l}\text { Chronic } \\
\text { pancreatitis }\end{array}$ & 11,960 & 65 & & 9.8 & 7.4 & 5.2 \\
\hline \multicolumn{2}{|l|}{ Average } & 、 & & & & & 7.3 \\
\hline
\end{tabular}

8. Three $\mathrm{ml}$. of $\mathrm{N} / 10 \mathrm{HCl}$ are added to tube with $1 \mathrm{ml}$. of packed cells and plasma, stirred up and transferred quantitatively to tissue grinder (in ice bath). Repeat two more times. Therefore, a total of $9 \mathrm{ml}$. $\mathrm{N} / 10 \mathrm{HCl}$ is added, diluting the cell plasma suspension ten-fold.

9. Extract is ground ten minutes, transferred to centrifuge tube and centrifuged about seven to eight minutes.

Viscosimetric determination of lysozyme is done on this extract.

\section{Calculation of lysozyme in granulocytes}

1. Calculate units of lysozyme per $\mathrm{ml}$. of plasma-cell suspension.

2. Calculate the total number of granulocytes in total volume of plasma cell suspension from WBC and differential.

3. Lysozyme per $10^{2}$ cells equals lysozyme units $/ \mathrm{ml}$. of plasma-packed cell suspension (contains total number of granulocytes) divided by total number of granulocytes
Accuracy: Because of the great number of possible sources of error, the utmost precautions were taken, particularly in the obtaining of the granulocyte count from the total leukocyte count and differential. In four duplicate experiments, the range of difference was $12 \%$ (Table II). In spite of this large factor of error, it is obvious that the lysozyme titre in the granulocyte of normal individuals has a great deal of variation, the lowest being 4.0 units per $10^{7}$ granulocytes and the highest being 12 units per $10^{r}$ granulocytes. There is also a fluctuation from day to day in one individual although only over a range of plus or minus 4 units.

In the disease states studied, the average unit of lysozyme per $10^{7}$ granulocytes was approximately the same as in normal controls. This was true even of disease associated with a tremendous daily loss of granulocytes.

Sympathomimetic agents (adrenalin) and parasympathomimetic agents (mecholyl) did not alter the titre of lysozyme in the granulocytes of one normal adult. This was shown by giving a large dose of each drug, and 20 minutes later determining the lysozyme titre of the granulocytes.

Normal level-5.7 units per $10^{7}$ granulocytes After $20 \mathrm{mg}$. mecholyl I.M. -6.5 units per $10^{7}$ granulocytes

After $1 \mathrm{ml}$. adrenalin (Parke-Davis)-6.2 units per $10^{7}$ granulocytes

The adrenalin produced a marked leukocytosis without altering the lysozyme titre.

Another possibility requiring consideration was the capacity of granulocytes to pick up lysozyme from the surrounding media. In order to determine whether or not living granulocytes are able to pick up lysozyme in vitro, the following experiments were carried out:

1. Twenty to $25 \mathrm{ml}$. of blood from one normal donor were collected over heparin in each of two tubes and a plasma suspension of leukocytes separated in accordance with the Minor-Burnett procedure. Counts were made on the cell suspension.

2. To a measured volume of plasma suspension in the first tube, $2 \mathrm{ml}$. of $0.9 \% \mathrm{NaCl}$ were added; to an equal volume of plasma suspension in the second tube, $2 \mathrm{ml}$. of egg-white lysozyme solution (prepared from Armour egg-white lysozyme), equivalent to a total of 200 micrograms or $210-270$ units, were added.

3. The tubes were mixed by inversion and placed in a 
water bath at $37^{\circ} \mathrm{C}$ for $1 / 2$ to $33 / 4$ hours, during which time they were mixed intermittently.

4. The suspensions were centrifuged and lysozyme determinations made on the packed cells and on the supernatant plasma.

In two separate experiments, the lysozyme added was almost completely recovered in the supernatant plasma, and the concentration of lysozyme in the packed cells of the control tube was essentially the same as that in the experimental tube. A third experiment was run, substituting a diluted solution of human tears for egg-white lysozyme solution, and similar results were obtained. It was apparent then, under the conditions of our experiments, that living leukocytes do not pick up lysozyme from the surrounding medium of plasma.

\section{DISCUSSION}

The high concentration of lysozyme which is present in the colonic exudate in patients with ulcerative colitis has been correlated in the present studies with the presence of large numbers of granulocytes. When steps were taken to separate the leukocytes from the mucus in such exudate, it was found that the mucus fraction was devoid of lysozyme activity unless considerable autolysis of the white cells had occurred. With degradation of the white cells, lysozyme in active form remained present in the surrounding medium. It seems clear, therefore, that the high concentration of lysozyme which is found in the stools of patients with ulcerative colitis is derived from granulocytes.

In the present investigation it has also been shown that substantial quantities of lysozyme are present in the circulating granulocytes of both normal and diseased individuals, in confirmation of the previous work of Gottschall and others. It appears, therefore, that the lysozyme in the feces in ulcerative colitis is derived primarily from the circulatory granulocyte.

Theoretically, it seemed possible that the granulocyte might absorb lysozyme from some external source. In vitro studies with suspensions of lysozyme, both egg-white and human, and granulocytes failed to yield any evidence that such absorption did occur. This possibility, therefore, appears unlikely.

It was of interest that the colonic exudate of patients with ulcerative colitis in symptomatic remission contained large quantities of leukocytes and large amounts of lysozyme. All of the patients who were subjected to this study continued to present gross evidence of inflammation of the rectum on proctoscopic examination. Further studies of this type on individuals in symptomatic remission, with proctoscopic findings which have reverted to a normal picture, seem indicated.

Our studies do not conclusively solve the question of a destructive action of lysozyme on colonic mucosa which might contribute to the perpetuation of inflammatory changes in the colon in ulcerative colitis. The possibility remains that this enzyme may contribute to the continuation of the inflammatory process. The weight of evidence, however, supports the view that the lysozyme in the bowel is only a manifestation of the extent of leukocytic infiltration.

\section{SCMMARY}

1. The primary source of the lysozyme found in the stools of patients with ulcerative colitis is the invading granulocyte.

2. The lysozyme remains in active form following dissolution of the white cell body.

3. The lysozyme titre of the lining mucus obtained from the rectum in patients with ulcerative colitis remains high in spite of complete symptomatic remission of the disease.

4. The average lysozyme content of the granulocyte is 8 units per $10^{7}$ cells with considerable individual variation and slight daily variation in the same individual.

5. Administration of sympathomimetic (adrenalin) and parasympathomimetic (mecholyl) drugs did not alter the lysozyme content of the granulocyte.

6. The granulocyte has no capacity to pick up human or egg-white lysozyme from a surrounding medium of plasma.

\section{ACKNOWLEDGMENT}

The authors greatly appreciate the advice and encouragement of Dr. Karl Meyer, who also made available the supply of mucinase used in this work.

\section{REFERENCES}

1a. Fleming, A., On a remarkable bacteriolytic element found in tissues and secretions. Proc. Roy. Soc., London s.B., 1922, 93, 306. 
b. Fleming, A., Lysozyme; president's address. Proc. Roy. Soc. Med., 1932, 26, 71.

2. Meyer, K., and Hahnel, E., The estimation of lysozyme by a viscosimetric method. J. Biol. Chem., 1946, 163, 723.

3. Thompson, R., Lysozyme and its relation to the antibacterial properties of various tissues and secretions. Arch. Path., 1940, 30, 1096.

4a. Meyer, K., Prudden, J. F., Lehman, W. L., and Steinberg, A., Lysozyme activity in ulcerative alimentary diseases: lysozyme activity in chronic ulcerative colitis. Am. J. Med., 1948, 5, 496.

b. Meyer, K., Gellhorn, A., Prudden, J. F., Lehman, W. L., and Steinberg, A., Lysozyme in chronic ulcerative colitis. Proc. Soc. Exper. Biol. \& Med., 1947, 65, 221.

5. Wang, K. J., Grant, R., Janowitz, H. D., and Grossman, M. I., Action of lysozyme on gastrointestinal mucosa. Arch. Path., 1950, 49, 298.

6. Glass, G. B. J., Pugh, B. L., Grace, W. J., and Wolf, S., Observations on the treatment of human gastric and colonic mucus with lysozyme. J. Clin. Invest., 1950, 29, 12.

7. Gray, S. J., Reifenstein, R. W., Benson, J. A., Jr., and Young, J. C. G., Treatment of ulcerative colitis and regional enteritis with ACTH. Arch. Int. Med., 1951, 87, 646.

8. Gray, S. J., Reifenstein, R. W., Connolly, E. P., Spiro, H. M., and Young, J. C. G., Studies on lysozyme in ulcerative colitis. Gastroenterology, 1950, 16, 687.

9. Prudden, J. F., Lane, N., and Meyer, K., Lysozyme content of granulation tissue. Proc. Soc. Exper. Biol. \& Med., 1949, 72, 38.

10. Sammons, H. G., Mucinases in ulcerative colitis. Gastroenterologia, 1950-51, 76, 346.

11. Gottschall, G., Pickering, J., and Tabachnik, D., Personal communication.

12. Minor, A. H., and Burnett, L., A method for obtaining living leukocytes from human peripheral blood by acceleration of erythrocyte sedimentation. Blood, 1948, 3, 799. 